
www.globaljournalseries.com, Email: info@globaljournalseries.com

\title{
AGRICULTURAL POTENTIALS OF FLOODPLAIN SOILS WITH CONTRASTING PARENT MATERIAL IN CROSS RIVER STATE, NIGERIA
}

AFU, S. M., ISONG, I. A. AND AWAOGU, C. E.

(Received 9 January 2019; Revision Accepted 4 February 2019)

\begin{abstract}
This paper reports the soil properties and agricultural potential of floodplain soil in Obufa Esuk Orok, Calabar and Awi, Akamkpa, Cross River State and characterized the soils to develop a baseline for soil improvement and increased agricultural productivity. Floodplain soil developed on coastal plain sand and basement complex soils were examined with regards to their physical and chemical properties. The results showed that both soils were coarse-textured with a high content of sand exceeding $70 \%$, giving dominant textural classes of loamy sand and sandy loam. The soils were strongly to slightly acid in reaction with mean surface $\mathrm{pH}$ values of 5.54 and 5.43 for soil developed on coastal plain sand and basement complex. The surface soil developed in coastal plain sand within Obufa Esuk Orok, Calabar contains moderate amount of exchangeable $\mathrm{Mg}(0.8-2.2 \mathrm{cmol} / \mathrm{kg})$, available $\mathrm{P}(10.0-11.83 \mathrm{mg} / \mathrm{kg})$, total N $(0.20-0.25$ $\%)$ and organic carbon (2.51-3.05\%) and was high in base saturation (93.11-95.50\%) and low in exchangeable acidity. Conversely, the floodplain soil developed on basement complex in Awi, Akamkpa was rated low in key fertility indicators. Hence, floodplain soil under this study notably, those developed on coastal plain soil can be exploited for the cultivation of rice, oil palm, coconut, plantain, pineapple, pepper, fluted pumpkin and sugar cane with judicious application of lime, and $\mathrm{N}$ and $\mathrm{K}$ fertilizer.
\end{abstract}

KEYWORDS: Floodplain Soil, Soil Fertility, Coastal Plain Soil, Basement Complex

\section{INTRODUCTION}

Food security is a first priority for the poor, especially people living in Sub-Sahara Africa. The projected world population estimated to be about 8.5 billion in 2030 (United Nations Population Division, 2015), has created concerned for many world economies including Nigeria. This increased population means increased resources will be required for meeting the demands of the growing population. However, agriculture can help tremendously in providing most of these resources, thus ensuring food security. In Nigeria, agriculture is the major source of livelihood for most of its populace, especially those living in the rural areas; it is the source of food and income for those who are engaged in the sector. With this rapidly increasing population, there is now need to intensify effort in meeting the increasing demand for food sustainably.

Currently, there is widespread decline in the yields of most upland crops in already existing agricultural land. This decline is primarily due to depletion of soil nutrients as a result of continuous cultivation (Yebo, 2015) and soil degradation (Yusuf and Yusuf, 2008). The few available fertile upland soils that would have helped to boost crop productivity and yields have been erroneously appropriated for non-agricultural purposes (i.e. urban, infrastructural or industrial uses), thus making upland soils for agriculture a scare resource (Aki, 2012; Aki and Isong, 2018).

It is now clear that an indispensable sector of Nigeria economy (i.e. agriculture) is facing serious constraints of scarcity of land and decline in soil fertility (Udo et al., 2009). This could underscore why Nigeria was among countries that were affected with the last global food crisis (Oparaeke et al., 2010) and has recently been enlisted as one of the poorest countries in the world. Therefore, it is necessary that pragmatic steps be taken to save Nigerians from an impending danger of more serious food crises in the near future.

Nevertheless, the problems related to land scarcity and/or declining productivity from upland agriculture could be alleviated through expansion of available cropping land into floodplain soils. Floodplain soil is an area of land adjacent to a stream or river which stretches from the banks of its channel to the base of the enclosing valley wall, and which experiences flooding during periods of high discharge (Goudie, 2004). The soils usually consist of levees, silts and sand deposited during floods. In recent times, agricultural use of floodplain soils has increased significantly in many developing countries particularly in Africa including Nigeria (Ogban and Ibia, 1998; Onyekwere et al., 2001; Ogban et al., 2011; McCartney et al., 2010; Akpan-Idiok

Afu, S. M., Department of Soil Science University of Calabar, Calabar, Nigeria

Isong, I. A., Department of Soil Science University of Calabar, Calabar, Nigeria

Awaogu, C. E., Department of Soil Science University of Nigeria, Nsukka, Nigeria 
and Ogbaji, 2013; Akpan et al., 2017). Soils of the floodplain have been characterized by moderate to high contents of basic cations, organic carbon, moderate to strong acidity and rated moderate to high in fertility status (Ogban and Babalola, 2009; Hossain et al., 2011). Floodplain soils being the nature's free gift could mitigate the problem of water unavailability, and if properly harnessed could sustain long growing season crops (Juo and Hossner, 1992) compared to upland soils.

Worldwide, floodplains soils are useful for agricultural production as they constitute a huge reserve of available nutrients for utilization by crops (Akpan-Idiok ans Ogbaji, 2013), and in Southeast Nigeria, extensive research has been done on floodplain soils and/ or wetland soils, and several studies have focused on the agro-potential of wetland (Aki, 2012; Akpan et al., 2017; Ogban and Babalola, 2009; Egbuchua and Ojobor, 2011; Ayalew and Beyene, 2012), geomorphologic aspects, classification and characterization of wetland agro-ecosystems (Chukwu et al., 2009; Nsor, 2017). Despite the over-whelming acceptance of floodplain soils for agriculture, those located within Obufa Esuk Orok, Calabar and Awi, Akamkpa have little been studied and are currently under-utilized and their soil qualities and agricultural potential to support crop growth and yield is unknown.

Although, wide variations in nutrient contents exist between upland soils developed on different parent materials within the same climatic condition and geographical location in Cross River State (Gbadegesin et al., 2011, Afu et al., 2017) and elsewhere, but it is not clear if there would be similar significant differences in nutrient contents of floodplain soils developed on different parent material within the same environmental condition, bearing in mind that in all floodplain soils, fresh materials are frequently added through depositions and are characterized with a mixture of clay, silts, sands, and organic materials, and therefore, would both be considered to have high and similar soil fertility status and hence, potential for crop production (Reddy and DeLaune, 2008; Daniel et al., 2017).

Thus, there is a need for testing the floodplain soils located on soils of two parent materials in Cross River State to find out if there are differences in soil properties between the two soils and to avoid a situation whereby a wrong soil management practice is imposed upon the soil in the event of allocating it for crop cultivation. This paper therefore intends to generate data and information on the physical and chemical properties of floodplain soil in Obufa Esuk Orok and Awi in Cross River State that would serve as a convenient and quick guide to the suitability or otherwise of the soil for crop cultivation.

\section{MATERIALS AND METHODS}

\section{Description of the study Area}

The study was conducted in Obufa Esuk Orok, Calabar, (Latitudes $4^{\circ} 15^{\prime}$ and $5^{\circ} 05^{\prime} \mathrm{N}$ and Longitudes $8^{\circ} 10^{\prime}$ and $8^{\circ} 30^{\prime} \mathrm{E}$ ) and Awi, Akamkpa (Latitudes $5^{\circ} 00^{\prime}$ and $5^{\circ} 57^{\prime} \mathrm{N}$ and Longitudes $8^{\circ} 06^{\prime}$ and $\left.9^{\circ} 0^{\prime} \mathrm{E}\right)$ Cross River State, Southeastern Nigeria (GPS, 2017). The area lies within the humid tropical climatic environment characterized by two distinct seasons; wet and dry. The rainy season usually starts from April and ends in October with a double peak usually in July and September, while the dry season spans from November to March. This area receives average annual rainfall exceeding $2600 \mathrm{~mm}$. The relative humidity is usually high averaging $85 \%$. The mean annual temperature of the area is about $27^{\circ} \mathrm{C}$ with February and March being the warmest month (Amalu and Isong, 2017). The principal crops grown in the area include maize, sugar cane, cassava, oil palm and vegetable crops.

\section{FIELD STUDY}

A total of twenty (20) composite soil samples were collected each from soil developed on coastal plain sand and basement complex rock. The samples were collected with the aid of a soil auger at the depths of 0 15 and 15-30 corresponding to surface and subsurface soils respectively. Soil samples collected were properly labeled in an airtight and clean polythene bags and taken to the laboratory where they were air-dried, then gently grounded, sieved in a $<2 \mathrm{~mm}$ sieve and the fine earth fractions were subjected to routine laboratory analysis.

\section{LABORATORY ANALYSES}

Particle size distribution was determined by Bouyoucos hydrometer method (Gee and Or, 2002). Soil pH $\left(\mathrm{H}_{2} \mathrm{O}\right)$ was measured electrometrically using glass electrode $\mathrm{pH}$ meter in a solid-liquid ratio of 1:2.5 following the procedure outlined by Udo et al. (2009). Total organic carbon was analyzed by wet digestion method (Nelson and Sommers, 1996). Total nitrogen content of the soil was determined by wet-digestion, distillation and titration procedures of the Kjeldahl method as described by Bremner (1996). Phosphorous was determined by Bray I method according to the procedure of Kuo (1996). The exchangeable bases were determined through extraction method with $1 \mathrm{M}$ ammonium acetate at $\mathrm{pH} 7$ (Thomas, 1982). Amounts of $\mathrm{Ca}$ and $\mathrm{Mg}$ ions in the leachate were analyzed by atomic absorption spectrophotometer, while $\mathrm{K}$ and $\mathrm{Na}$ ions were analyzed by flame photometer. Exchangeable acidity (hydrogen and aluminum) were determined by the titrimetric method using $1 \mathrm{~N} \mathrm{KCl}$ extract. The percent base saturation of the soil was calculated as the percentage of the sum of the basic exchangeable cations ( $\mathrm{Ca}, \mathrm{Mg}, \mathrm{K}$ and $\mathrm{Na}$ ) to the ECEC of the soil.

\section{STATISTICAL ANALYSIS}

The data obtained from laboratory analysis were subjected to both descriptive and inferential statistic. Descriptive statistics; mean and range of soil properties were computed and employed to compare the results with critical values. t-test was also computed to compare if there was any significant difference between soil properties in the two parent materials.

\section{RESULTS AND DISCUSSION}

The physico-chemical properties of floodplain soils are shown in Tables 1 and 2.

Physical Properties of the investigated soil samples The results as presented in Tables 1,2 and 3 showed that there were no considerable differences in soil particle size distribution in both surface and sub-surface soil in the two parent materials studied. In floodplain soil developed on coastal plain sand, the mean sand, silt and clay content for surface soil were 77.0, 21.3 and 17.4, respectively and $78.8,15.4$ and $5.8 \%$ for 
subsurface soil. Whereas in soil developed on basement complex, the mean sand, silt and clay content for surface soil were $77.9,16.4$ and $5.7 \%$, and 78.1 , 17.0 and $4.9 \%$ for subsurface soil respectively. The trend in percent sand, silt and clay movement with soil depth in both parent materials were irregular. The soils are coarse-textured with a high content of sand exceeding $70 \%$, giving dominant textural classes of loamy sand and sandy loam. Similar textural classes of loamy sand and sandy loam were also obtained in coastal plain soils in Imo state (Oguike and Mbagwu, 2009; Ukabiala et al., 2016) and in Akpabuyo, South East Nigeria, (Akpan-Idiok et al., 2012). The soil texture observed in this study also corroborate the findings of Ibanga et al. (2005), Aki (2012), Nsor (2017) and Akpan et al. (2017) who did similar studies on soils of Cross River State, Nigeria.

The difference in particle size distributions between coastal plain sand and basement complex rock were not statistically significant as depicted by the t-test values $(\mathrm{t}$ $=-0.061, \mathrm{df}=9, \mathrm{p}>0.05),(\mathrm{t}=-0.235, \mathrm{df}=9, \mathrm{p}>0.05),(\mathrm{t}$ $=0.394 ; \mathrm{df}=9, \mathrm{p}>0.05)$ for sand, silt and clay, respectively (Table 3). This result contrast the report of Esu et al. (2014) and Yakubu and Ojanuga (2000) that topography, soil depth and parent materials are attributable to differences in pattern of soil distribution and properties of soil over landscape but corroborates the report of Reddy and DeLaune (2008) and Daniel et al. (2017) that in all floodplain soils, fresh materials are frequently added through depositions and are characterized with a mixture of clay, silts, sand, which may perhaps have similar properties. The texture observed irrespective of depth and parent materials can be favourable for agricultural cultivation. Most field crops could grow well in soils having sandy loam, loamy sand and sandy clay loam textural class as these soils have a potentially well-balanced capacity to retain water, form a stable structure and provide adequate aeration (Amalu and Isong, 2018).

\section{Chemical Properties}

The results of selected chemical properties of the soils are also presented in Tables 1 and 2. Interpretation of results was based on the fertility ratings of Landon (1991) and FPDD (1990) established for Nigerian soils. pH

The result as shown in Tables 3 indicates that there was no significant difference in soil $\mathrm{pH}$ between coastal plain sand and basement complex $(\mathrm{t}=-1.425$, df $=9, \mathrm{p}>$ 0.05) (Table 3). In floodplain soil developed on coastal plain soil, the mean $\mathrm{pH}$ for surface and sub-surface soil were 5.54 and 5.28. Whereas in soil developed on basement complex, the mean $\mathrm{pH}$ for surface and subsurface soil were 5.43 and 5.75 . The values of $\mathrm{pH}$ obtained for this study indicated that the soils were strongly to moderately acid in soil reaction (Landon, 1991). This $\mathrm{pH}$ value is an indication that significant amount of exchangeable $\mathrm{Al}^{3+}$ and $\mathrm{H}^{+}$are present to affect plant growth (Udo et al., 2009). Although, Brady and Weil (2002) had established $\mathrm{pH}$ range of 5.5-7.0 as optimal for overall satisfactory availability of plant nutrients but the values obtained from this study is however lower. Nevertheless, the soil could be utilized for crop cultivation with judicious application of lime. 
AFU, S. M., ISONG, I. A. AND AWAOGU, C. E.

TABLE 1: Physico-chemical properties of floodplain soil developed on coastal plain sand in Calabar

\begin{tabular}{|c|c|c|c|c|c|c|c|c|c|c|c|c|c|c|c|c|c|}
\hline & \multirow[t]{3}{*}{ Soil depth $(\mathrm{cm})$} & \multicolumn{3}{|c|}{ Particle size } & \multirow[t]{3}{*}{ Texture } & \multirow{3}{*}{$\begin{array}{l}\mathrm{pH} \\
\left(\mathrm{H}_{2} \mathrm{O}\right)\end{array}$} & \multirow[t]{2}{*}{ OC } & \multirow[t]{2}{*}{$\mathrm{TN}$} & \multirow{2}{*}{\multicolumn{2}{|c|}{$\begin{array}{l}\text { AV.P } \\
(\mathrm{mg} / \mathrm{kg})\end{array}$}} & \multicolumn{3}{|c|}{ Exch. Cations } & \multicolumn{2}{|c|}{ Exch. Acidity } & \multirow[t]{3}{*}{ ECEC } & \multirow[t]{3}{*}{ BS ( \%) } \\
\hline & & \multirow{2}{*}{$\begin{array}{r}\text { Sand } \\
\longrightarrow\end{array}$} & \multirow{2}{*}{$\begin{array}{l}\text { Silt } \\
\%\end{array}$} & \multirow{2}{*}{$\longleftarrow^{\text {Clay }}$} & & & & & & & $\mathrm{Mg}$ & $\mathrm{K}$ & $\mathrm{Na}$ & $\mathrm{Al}^{+3}$ & $\mathrm{H}^{+}$ & & \\
\hline & & & & & & & $\leftarrow$ & $\%$ & $\rightarrow$ & & & $\rightarrow 0$ & $\mathrm{o} / \mathrm{kg}$ & $\leftarrow$ & & & \\
\hline \multirow[t]{2}{*}{ A } & $0-15$ & 68 & 21 & 11.0 & Sandy loam & 5.6 & 3.05 & 0.25 & 10 & 5.2 & 1.2 & 0.09 & 0.08 & 0.0 & 0.36 & 6.93 & 94.8 \\
\hline & $15-30$ & 74 & 19 & 7.0 & Sandy loam & 4.5 & 2.23 & 0.18 & 9.75 & 2.4 & 1.0 & 0.07 & 0.05 & 1.64 & 1.32 & 6.48 & 54.3 \\
\hline \multirow[t]{2}{*}{ B } & $0-15$ & 74 & 20 & 6.0 & Sandy loam & 5.5 & 3.0 & 0.24 & 11.13 & 5.0 & 0.8 & 0.08 & 0.06 & 0.0 & 0.28 & 6.22 & 95.5 \\
\hline & $15-30$ & 83 & 12 & 5.0 & Loamy sand & 5.1 & 2.35 & 0.19 & 11.5 & 3.8 & 1.4 & 0.09 & 0.07 & 0.20 & 0.80 & 6.36 & 84.3 \\
\hline \multirow[t]{2}{*}{ C } & $0-15$ & 80 & 16 & 4.0 & Loamy sand & 5.7 & 2.63 & 0.21 & 10.75 & 4.2 & 2.0 & 0.09 & 0.07 & 0.0 & 0.32 & 6.68 & 95.2 \\
\hline & $15-30$ & 74 & 17 & 9.0 & Sandy loam & 5.5 & 1.82 & 0.14 & 10.0 & 3.0 & 2.0 & 0.08 & 0.07 & 0.24 & 0.52 & 5.91 & 87.1 \\
\hline \multirow[t]{2}{*}{$\mathrm{D}$} & $0-15$ & 82 & 15 & 3.0 & Loamy sand & 5.2 & 2.51 & 0.20 & 10.88 & 4.4 & 2.2 & 0.06 & 0.05 & 0.0 & 0.40 & 7.11 & 94.4 \\
\hline & $15-30$ & 81 & 15 & 4.0 & Loamy sand & 5.7 & 1.29 & 0.18 & 11.63 & 3.4 & 3.6 & 0.08 & 0.07 & 0.44 & 0.48 & 8.07 & 88.6 \\
\hline \multirow[t]{2}{*}{$E$} & $0-15$ & 81 & 15 & 4.0 & Loamy sand & 5.7 & 2.73 & 0.22 & 11.83 & 2.8 & 1.4 & 0.07 & 0.06 & 0.0 & 0.32 & 4.65 & 93.11 \\
\hline & $15-30$ & 82 & 14 & 4.0 & Loamy sand & 5.6 & 2.27 & 0.18 & 12.0 & 3.0 & 4.0 & 0.08 & 0.05 & 0.16 & 0.72 & 8.01 & 89.0 \\
\hline \multicolumn{18}{|c|}{ Surface sample } \\
\hline \multicolumn{2}{|c|}{ Min } & 68.0 & 18.0 & 3.0 & & $5 . .20$ & 2.51 & 0.20 & 10.00 & 2.8 & 0.8 & 0.06 & 0.05 & 0.00 & 0.28 & 4.65 & 93.11 \\
\hline \multicolumn{2}{|c|}{$\operatorname{Max}$} & 82.0 & 21.0 & 11.0 & & 5.70 & 3.05 & 0.25 & 11.83 & 5.2 & 2.2 & 0.09 & 0.08 & 0.00 & 0.40 & 7.11 & 95.50 \\
\hline \multicolumn{2}{|c|}{ Mean } & 77.0 & 17.4 & 5.6 & & 5.54 & 2.78 & 0.22 & 10.92 & 4.3 & 1.5 & 0.08 & 0.06 & 0.00 & 0.34 & 6.32 & 94.60 \\
\hline \multicolumn{2}{|c|}{ SD } & 5.92 & 2.88 & 3.21 & & 0.21 & 0.23 & 0.02 & 0.66 & 0.9 & 0.58 & 0.01 & 0.01 & 0.00 & 0.05 & 0.99 & 0.93 \\
\hline \multirow{2}{*}{\multicolumn{2}{|c|}{$\begin{array}{l}\text { CV (\%) } \\
\text { Sub-surface sample }\end{array}$}} & 7.7 & 16.6 & 57.3 & & 3.7 & 8.4 & 9.3 & 6.1 & 21.9 & 37.9 & 16.7 & 17.8 & & 13.6 & 15.7 & 1.0 \\
\hline & & & & & & & & & & & & & & & & & \\
\hline \multicolumn{2}{|c|}{ Min } & 74.0 & 12.0 & 4.0 & & 4.50 & 1.29 & 0.14 & 9.75 & 2.4 & 1.0 & 0.07 & 0.05 & 0.16 & 0.48 & 5.91 & 54.30 \\
\hline \multicolumn{2}{|c|}{ Max } & 83.0 & 19.0 & 9.0 & & 5.70 & 2.35 & 0.19 & 12.00 & 3.8 & 4.0 & 0.09 & 0.07 & 1.64 & 1.32 & 8.07 & 89.00 \\
\hline $\mathrm{Me}$ & & 78.8 & 15.4 & 5.8 & & 5.28 & 1.99 & 0.17 & 10.98 & 3.12 & 2.4 & 0.08 & 0.06 & 0.54 & 0.77 & 6.97 & 80.66 \\
\hline SD & & 4.44 & 2.7 & 2.17 & & 0.49 & 0.44 & 0.02 & 1.03 & 0.5 & 1.3 & 0.01 & 0.01 & 0.63 & 0.34 & 1.00 & 14.85 \\
\hline & & 5.6 & 17.5 & 37.4 & & 9.3 & 22.2 & 11.2 & 9.3 & 16.7 & 55.6 & 17.7 & 17.7 & 116.9 & 43.8 & 14.4 & 18.4 \\
\hline & all mean & 77.9 & 16.4 & 5.7 & & 5.41 & 2.39 & 0.19 & 10.95 & 3.72 & 1.96 & 0.06 & 0.06 & 0.27 & 0.55 & 6.64 & 87.63 \\
\hline
\end{tabular}

$\mathrm{OC}=$ organic carbon; $\mathrm{OM}=$ organic matter; $\mathrm{TN}=$ Total nitrogen; $\mathrm{AV} . \mathrm{P}=$ available phosphorus; $\mathrm{BS}=$ base saturation; $\mathrm{ECEC}$ effective cation exchange capacity 
AGRICULTURAL POTENTIALS OF FLOODPLAIN SOILS WITH CONTRASTING PARENT

Table 2: Physico-chemical properties of floodplain soil developed on basement complex in Akamkpa

\begin{tabular}{|c|c|c|c|c|c|c|c|c|c|c|c|c|c|c|c|c|c|}
\hline & \multirow{3}{*}{$\begin{array}{l}\text { Soil depth } \\
\text { (cm) }\end{array}$} & \multicolumn{3}{|c|}{ Particle size } & \multirow{3}{*}{ Texture } & \multirow{3}{*}{$\begin{array}{l}\mathrm{pH} 5.5 \\
\left(5.8 \mathrm{H}_{2}\right. \\
\text { O5.75) }\end{array}$} & \multirow[t]{2}{*}{ OC } & \multirow[t]{2}{*}{$\mathrm{TN}$} & \multirow{3}{*}{$\begin{array}{l}\text { AV. P } \\
\left(\mathrm{mgkg}^{-1}\right)\end{array}$} & \multicolumn{3}{|c|}{ Exch. cations } & \multicolumn{3}{|c|}{ Exch. Acidity } & \multirow[t]{3}{*}{ ECEC } & \multirow[t]{3}{*}{ BS (\%) } \\
\hline & & $\begin{array}{l}\text { San } \\
d\end{array}$ & Silt & Clay & & & & & & $\mathrm{Ca}$ & $\mathrm{Mg}$ & $\mathrm{K}$ & $\mathrm{Na}$ & $\mathrm{Al}^{+3}$ & $\mathrm{H}^{+}$ & & \\
\hline & & $\longrightarrow$ & $\%$ & $\leftarrow$ & & & $\leftarrow \%$ & $\rightarrow$ & & - & $\rightarrow$ & $\mathrm{cmol}^{+} \mathrm{kg}^{-1}$ & $\leftarrow$ & & & & \\
\hline \multirow[t]{2}{*}{$A$} & $0-15$ & 78.3 & 17.0 & 4.7 & Loamy sand & 5.15 & 1.96 & 0.16 & 6.87 & 1.2 & 3.0 & 0.07 & 0.07 & 0.28 & 0.38 & 4.98 & 87.15 \\
\hline & $15-20$ & 73.3 & 19.0 & 7.7 & Sandy loam & 5.2 & 1.22 & 0.10 & 5.75 & 2.2 & 1.2 & 0.08 & 0.07 & 0.40 & 0.36 & 4.31 & 82.37 \\
\hline \multirow[t]{2}{*}{ B } & $0-15$ & 78.3 & 16.0 & 5.7 & Loamy sand & 5.15 & 2.15 & 0.18 & 4.60 & 4.0 & 2.0 & 0.09 & 0.05 & 0.24 & 0.40 & 6.78 & 90.56 \\
\hline & $15-20$ & 83.3 & 12.0 & 4.7 & Loamy sand & 5.6 & 0.86 & 0.07 & 6.12 & 3.2 & 1.2 & 0.08 & 0.06 & 0.16 & 0.52 & 5.22 & 86.97 \\
\hline \multirow[t]{2}{*}{ C } & $0-15$ & 81.3 & 10.0 & 8.7 & Loamy sand & 5.6 & 0.9 & 0.03 & 5.0 & 1.8 & 1.0 & 0.06 & 0.05 & 0.18 & 0.56 & 3.65 & 79.73 \\
\hline & $15-20$ & 78.3 & 18.0 & 3.7 & Loamy sand & 5.9 & 0.7 & 0.06 & 5.25 & 4.0 & 0.8 & 0.08 & 0.06 & 0.40 & 0.24 & 5.58 & 88.53 \\
\hline \multirow[t]{2}{*}{$D$} & $0-15$ & 78.3 & 17.0 & 4.7 & Loamy sand & 5.5 & 1.3 & 0.10 & 5.87 & 2.4 & 1.2 & 0.07 & 0.05 & 0.22 & 0.40 & 4.34 & 85.71 \\
\hline & $15-20$ & 77.3 & 18.0 & 4.7 & Loamy sand & 5.8 & 1.3 & 0.09 & 5.75 & 3.0 & 1.4 & 0.07 & 0.06 & 0.20 & 0.44 & 5.17 & 87.62 \\
\hline \multirow[t]{2}{*}{$E$} & $0-15$ & 73.3 & 22.0 & 4.7 & Sandy loam & 5.75 & 2.75 & 0.29 & 5.75 & 2.8 & 1.0 & 0.08 & 0.06 & 0.48 & 0.31 & 4.74 & 83.12 \\
\hline & $15-20$ & 78.3 & 18.0 & 3.7 & Loamy sand & 6.25 & 0.85 & 0.07 & 6.25 & 3.6 & 1.2 & 0.08 & 0.06 & 0.12 & 0.56 & 5.56 & 88.85 \\
\hline \multicolumn{18}{|c|}{ Surface sample } \\
\hline \multicolumn{2}{|c|}{ Min } & 73.3 & 10.0 & 4.7 & & 5.15 & 0.90 & 0.03 & 4.60 & 1.2 & 1.0 & 0.06 & 0.05 & 0.18 & 0.31 & 3.65 & 31.09 \\
\hline \multicolumn{2}{|c|}{ Max } & 81.3 & 22.0 & 8.7 & & 5.75 & 2.75 & 0.29 & 6.87 & 4.0 & 3.0 & 0.09 & 0.07 & 0.48 & 0.56 & 6.78 & 47.16 \\
\hline \multicolumn{2}{|c|}{ Mean } & 77.9 & 16.4 & 5.7 & & 5.43 & 1.81 & 0.15 & 5.62 & 2.4 & 1.6 & 0.07 & 0.056 & 0.28 & 0.41 & 4.89 & 35.62 \\
\hline \multicolumn{2}{|c|}{ SD } & 2.88 & 4.28 & 1.73 & & 0.27 & 0.73 & 0.09 & 0.88 & 1.1 & 0.86 & 0.01 & 0.01 & 0.12 & 0.09 & 1.17 & 6.54 \\
\hline \multirow{2}{*}{\multicolumn{2}{|c|}{$\begin{array}{l}\text { CV (\%) } \\
\text { Sub-surface }\end{array}$}} & 3.07 & 26.1 & 30.4 & & 5.0 & 40.1 & 0.64 & 15.6 & 43.5 & 52.7 & 15.4 & 16.0 & 42.0 & 22.4 & 23.8 & 18.3 \\
\hline & & & & & & & & & & & & & & & & & \\
\hline \multicolumn{2}{|c|}{ Min } & 73.3 & 12.0 & 3.70 & & 5.20 & 0.70 & 0.06 & 5.25 & 2.20 & 0.80 & 0.07 & 0.06 & 0.12 & 0.24 & 4.31 & 33.65 \\
\hline \multicolumn{2}{|c|}{ Max } & 83.3 & 19.0 & 7.70 & & 6.25 & 1.30 & 0.10 & 6.25 & 4.0 & 1.40 & 0.08 & 0.07 & 0.40 & 0.56 & 5.58 & 45.36 \\
\hline \multicolumn{2}{|c|}{ Mean } & 78.1 & 17.0 & 4.90 & & 5.75 & 0.99 & 0.07 & 5.82 & 3.20 & 1.16 & 0.078 & 0.06 & 0.26 & 0.42 & 5.17 & 39.68 \\
\hline \multicolumn{2}{|c|}{ SD } & 3.56 & 2.83 & 1.64 & & 0.387 & 0.26 & 1.6 & 0.39 & 0.68 & 0.22 & 0.004 & 0.004 & 0.13 & 0.13 & 0.52 & 4.211 \\
\hline \multicolumn{2}{|c|}{ CV (\%) } & 4.6 & 16.6 & 33.5 & & 6.7 & 26.3 & 21.1 & 6.7 & 21.2 & 18.9 & 5.7 & 7.0 & 5.3 & 30.0 & 10.0 & 10.6 \\
\hline
\end{tabular}

$\mathrm{OC}=$ organic carbon; $\mathrm{OM}=$ organic matter; TN = Total nitrogen; AV. $\mathrm{P}=$ available phosphorus; $\mathrm{BS}=$ base saturation; $\mathrm{ECEC}$ effective cation exchange capacity. 
Table 3: Differences in properties of floodplain soils developed on coastal plain sand and basement complex in Cross River State

\begin{tabular}{|c|c|c|c|c|c|c|}
\hline \multirow[t]{2}{*}{ Soil properties } & \multicolumn{2}{|c|}{ Mean \pm SD } & \multirow[b]{2}{*}{$\begin{array}{l}\text { Mean } \\
\text { difference }\end{array}$} & \multirow[b]{2}{*}{ t- test } & \multirow[b]{2}{*}{$\mathrm{df}$} & \multirow[b]{2}{*}{ Sig.(2-tail) } \\
\hline & $\begin{array}{l}\text { Coastal plain } \\
\text { sand }\end{array}$ & $\begin{array}{l}\text { Basement } \\
\text { complex }\end{array}$ & & & & \\
\hline Sand & $77.90 \pm 5.02$ & $78 \pm 3.057$ & -0.10 & -0.061 & 9 & $0.953^{\mathrm{NS}}$ \\
\hline Silt & $16.4 \pm 2.84$ & $16.7 \pm 3.43$ & -0.30 & -0.235 & 9 & $0.819^{N S}$ \\
\hline Clay & $5.7 \pm 2.58$ & $5.3 \pm 1.65$ & 0.40 & 0.394 & 9 & $0.703^{N S}$ \\
\hline $\mathrm{pH}$ & $5.4 \pm 0.38$ & $5.59 \pm 0.36$ & -0.18 & -1.425 & 9 & $0.188^{N S}$ \\
\hline Org. C & $2.39 \pm 0.53$ & $1.39 \pm 0.67$ & 0.98 & 5.331 & 9 & $<0.001^{* * *}$ \\
\hline Total N & $0.19 \pm 0.032$ & $0.12 \pm 0.076$ & 0.084 & 4.209 & 9 & $<0.001^{* * *}$ \\
\hline Avail. P & $10.95 \pm 0.81$ & $5.72 \pm 0.64$ & 5.23 & 16.001 & 9 & $<0.001^{* * *}$ \\
\hline Exch. Ca & $3.72 \pm 0.96$ & $2.82 \pm 0.93$ & 0.90 & 1.882 & 9 & $0.092^{*}$ \\
\hline Exch. Mg & $1.96 \pm 1.074$ & $1.40 \pm 0.65$ & 0.56 & 1.256 & 9 & $0.241^{\mathrm{NS}}$ \\
\hline Exch. K & $0.079 \pm 0.0099$ & $0.076 \pm 0.0084$ & 0.0030 & 0.669 & 9 & 0.520 NS \\
\hline Exch. $\mathrm{Na}$ & $0.063 \pm 0.011$ & $0.059 \pm 0.0074$ & 0.0040 & 1.078 & 9 & $0.309^{\mathrm{NS}}$ \\
\hline Exch. $\mathrm{H}^{+}$ & $0.55 \pm 0.32$ & $0.42 \pm 0.11$ & 0.135 & 1.283 & 9 & $0.231^{\mathrm{NS}}$ \\
\hline ECEC & $6.64 \pm 1.0$ & $5.03 \pm 0.86$ & 1.61 & 3.862 & 9 & $0.004^{\star \star *}$ \\
\hline PBS & $87.63 \pm 12.34$ & $37.65 \pm 5.61$ & 49.98 & 12.216 & 9 & $<0.001^{* \star *}$ \\
\hline
\end{tabular}

${ }^{* * *}=$ significant at $1 \%,{ }^{* *}=$ significant at $5 \% ;{ }^{*}=$ significant at $10 ; \mathrm{NS}=$ not significant; SD = Standard Deviation

\section{Organic carbon}

Organic carbon (OC) in floodplain soil developed on coastal plain sand ranged from 2.51-3.05 \% and 1.292.35 for surface and sub-surface soil with a mean value of 2.78 and $1.99 \%$ for surface and sub-surface soil respectively and was rated high for surface soil and moderate for sub-surface. Similarly, organic carbon in floodplain soil developed on basement complex ranged from $0.90-2.75 \%$ and $0.70-1.30 \%$ for surface and subsurface soil with a mean value of 1.81 and $0.99 \%$ for surface and sub-surface soil respectively and was rated moderate for surface soil and low for sub-surface. In both parent materials, $\mathrm{OC}$ decreased with increasing soil depth, probably due to decreased faunal activities in the underlying horizons (Browaldh, 1995; Lawal et al., 2014). The result also showed that there was a significant difference in soil organic carbon between the two parent materials studied $(t=5.33$, df $=9, p<0.01)$ (Table 3). Soil developed on coastal plain sand parent material had the highest organic matter content than basement complex soil. The high and moderate levels of organic carbon detected on the floodplains soils of both parent materials could be attributable to the accumulation of residues of the fallow vegetation over a long time and the deposits brought by flood water. The upland soil of the study area from other previous studies is however noted to have low organic carbon levels (Amalu and Isong, 2015; Afu et al., 2017) when compared to those obtained in floodplain soil for this study, and this can significantly promote crop production. Hence, it can be infer that floodplain soil has higher potential for crop production in terms of organic carbon supply.

\section{Total nitrogen}

Total nitrogen in floodplain soil developed on coastal plain sand parent material ranged from $0.20-0.25 \%$ and $0.14-0.19 \%$ for surface and sub-surface soil with a mean value of 0.22 and $0.17 \%$ for surface and subsurface soil respectively and was rated moderate for surface soil and low for sub-surface soil. Similarly, total nitrogen in floodplain soil developed on basement complex ranged from $0.03-0.29 \%$ and $0.06-0.10 \%$ for surface and sub-surface soil with a mean value of 0.15 and $0.07 \%$ for surface and sub-surface soil respectively and was rated low for both surface and sub-surface soil. Total nitrogen values were rated low in sub-surface soil of both parent materials. This low value of total nitrogen could be attributed to losses through leaching, percolation under flooded situation and volatilization once the flood water recedes especially under high temperature that characterized the study area (Brady and Weil, 2002). Thus, the results showed that soil developed on basement complex is deficient in nitrogen. This soil could be utilized for crop cultivation of crop with judicious application of $\mathrm{N}$ fertilizer. The low total $\mathrm{N}$ of the floodplain soil also conforms to the observations of Valiela and Teal (1974) that estuarine wetlands tend to have $\mathrm{N}$ limitations. The result further showed that there was a significant difference in total nitrogen between the two parent materials studied $(t=4.21$, $d f=9, p<0.001)$ (Table 3). Soil developed on coastal plain sand parent material had the highest total nitrogen content.

\section{Available phosphorus}

Available phosphorus in floodplain soil developed on coastal plain sand ranged from $10.0-11.83 \mathrm{mg} / \mathrm{kg}$ and $9.75-12.0 \mathrm{mg} / \mathrm{kg}$ for surface and sub-surface soil with a mean value of 10.92 and $10.98 \mathrm{mg} / \mathrm{kg}$ for surface and sub-surface soil respectively and was rated moderate for both surface and sub-surface soil. Ukpong (2000) reported high available $\mathrm{P}$ levels in the Creek / Calabar River swamps. Similarly, available phosphorus in floodplain soil developed on basement complex ranged from $4.6-6.87 \mathrm{mg} / \mathrm{kg}$ and $5.25-6.25 \mathrm{mg} / \mathrm{kg}$ for surface and sub-surface soil with a mean value of 5.62 and 5.82 $\mathrm{mg} / \mathrm{kg}$ for surface and sub-surface soil respectively and was rated low for both surface and sub-surface soil based on fertility rating of Landon (1991). The result further showed that there was a significant difference in available phosphorus between the two parent materials studied $(t=16.0, d f=9, p<0.001)$ (Table 3$)$. Soil 
developed on coastal plain sand parent material had the highest available phosphorus content than soil developed on basement complex. However, the present phosphorus content of the soil developed on coastal plain sand was within the critical limit of $8-20 \mathrm{mgkg}^{-1}$ stipulated for the "acid sands" of South-Eastern Nigeria (FPDD, 1990), whereas that obtained in soil developed on basement complex rock was below $8-20 \mathrm{mgkg}^{-1}$ critical value. The low available phosphorus encountered in soil developed on basement complex in the study area indicates that $P$ may be chemically bound as phosphates of $\mathrm{Fe}$ and $\mathrm{Al}$ owing to the observed low $\mathrm{pH}$ of the soil. This finding corroborates that of Nsor (2017) who also obtained the same result in similar soil. Uzoho et al., (2014) link low phosphorus content of soils to high soil acidity.

\section{Exchangeable cations}

The mean surface and subsurface soil values for exchangeable $\mathrm{Ca}$ were 4.30 and $3.12 \mathrm{cmol} / \mathrm{kg}$ for soil developed on coastal plain sand and 2.4 and 3.2 for soil developed on basement complex rock. Also, the mean surface and subsurface soil value for exchangeable $\mathrm{Mg}$ were 1.5 and $2.4 \mathrm{cmol} / \mathrm{kg}$ for soil developed on coastal plain sand and 1.60 and $1.16 \mathrm{cmol} / \mathrm{kg}$ for soil developed on basement complex rock. Similarly, the mean surface and subsurface soil value for exchangeable $\mathrm{K}$ were 0.08 and $0.08 \mathrm{cmol} / \mathrm{kg}$ for soil developed on coastal plain sand and 0.070 and $0.078 \mathrm{cmol} / \mathrm{kg}$ for soil developed on basement complex rock. The results obtained for exchangeable $\mathrm{K}$ in this study was somewhat comparable to $0.014,0.28$ and $0.09 \mathrm{cmol} / \mathrm{kg}$ for upper slope, middle slope and foot slope soils overlying basement complex in Southern Nigeria (Oku et al., 2010). The finding of this study is in agreement with the report of Attoe et al. (2016) who obtained higher value of exchangeable $\mathrm{K}$ in coastal plain sand soil (surface soil = $0.10 \mathrm{cmol} / \mathrm{kg}$; subsurface soil $=0.14 \mathrm{cmol} / \mathrm{kg})$ in Akamkpa than basement complex soil (surface soil = $0.08 \mathrm{cmol} / \mathrm{kg}$; subsurface soil $=0.08 \mathrm{cmol} / \mathrm{kg}$ ) in $\mathrm{lkot}$ Omin, but contrast the report of Abam and Orji (2019) who obtained lower exchangeable $K$ value of 1.3 $\mathrm{cmol} / \mathrm{kg}$ in soil developed on coastal plain sand than 1.6 $\mathrm{cmol} / \mathrm{kg}$ in soils developed on basement complex. Furthermore, the result also showed that the mean surface and subsurface soil values for exchangeable $\mathrm{Na}$ were 0.06 and $0.06 \mathrm{cmol} / \mathrm{kg}$ for soil developed on coastal plain sand and 0.056 and $0.06 \mathrm{cmol} / \mathrm{kg}$ for soil developed on basement complex. The result obtained for this study confirmed the findings of Ogban et al. (2011), that the soils of Southeastern Nigeria have low basic cations. However, among the basic cations determined only exchangeable $\mathrm{Mg}$ values in both soils were rated moderate when compared to fertility rating of Landon (1991). The rest of the exchangeable cations were rated low. The result further showed that the exchange complex of the soils was dominantly occupied by $\mathrm{Ca}$ and then followed by $\mathrm{Mg}$, whereas $\mathrm{K}$ and $\mathrm{Na}$ were very fewer compared to the former two divalent cations, and follows a decreasing cation magnitude, that is $\mathrm{Ca}^{2+}$ $>\mathrm{Mg}^{2+}>\mathrm{K}^{+}>\mathrm{Na}^{+}$. The difference in exchangeable cations of the soil between coastal plain sand and basement complex were not statistically significant as depicted by the t-test values $(t=1.88$, $d f=9, p>0.05)$, $(t=1.26, d f=9, p>0.05),(t=0.67, d f=9, p>0.05)$ and $(\mathrm{t}=1.07$; $\mathrm{df}=9, \mathrm{p}>0.05)$ for $\mathrm{Ca}, \mathrm{Mg}, \mathrm{K}$ and $\mathrm{Na}$ respectively.

\section{Effective Cation Exchange Capacity (ECEC)}

Effective cation exchange capacity (ECEC) in floodplain soil developed on coastal plain sand ranged from 4.657.11 and $5.91-8.07 \mathrm{cmol} / \mathrm{kg}$ for surface and sub-surface soil with a mean value of 6.32 and $6.97 \mathrm{cmol} / \mathrm{kg}$ for surface and sub-surface soil respectively and was rated low for both surface and sub-surface soil. Similarly, ECEC in floodplain soil developed on basement complex ranged from 3.65-6.78 and 4.31-5.58 cmol/kg for surface and sub-surface soil with a mean value of 4.89 and $5.17 \mathrm{cmol} / \mathrm{kg}$ for surface and sub-surface soil respectively and was rated low for both surface and subsurface soil. It has been reported elsewhere that the soils of Southeastern Nigeria have low ECEC and basic cations (Ogban et al., 2011). The low ECEC have been attributed to the fact that soils in this region are strongly weathered, have little or no content of weathered materials in sand and silt fractions and have predominantly Kaolinite in their clay fractions. This finding is also in agreement with that of Akpan et al. (2017) who work on wetland soil in Calabar and observed low ECEC. The result also showed that there was a significant difference in soil ECEC between coastal plain sand and basement complex $(\mathrm{t}=3.86$, $\mathrm{df}=$ $9, p<0.001$ ) (Table 3). Although, ECEC was low in both soils but soil developed on coastal plain sand parent material had the highest ECEC than soil developed on basement complex rock.

\section{Exchangeable Acidity}

Exchangeable acidity $\left(\mathrm{H}^{+}\right)$in floodplain soil developed on coastal plain sand ranged from $0.28-0.40$ and $0.48-$ $1.32 \mathrm{cmol} / \mathrm{kg}$ for surface and sub-surface soil with a mean value of 0.34 and $0.34 \mathrm{cmol} / \mathrm{kg}$ for surface and sub-surface soil, and was rated low for both surface and surface soil. Similarly, exchangeable acidity $\left(\mathrm{H}^{+}\right)$in floodplain soil developed on basement complex rock ranged from $0.31-0.56$ and $0.24-0.56 \mathrm{cmol} / \mathrm{kg}$ for surface and sub-surface soil with a mean value of 0.41 and 0.42 $\mathrm{cmol} / \mathrm{kg}$ for surface and sub-surface soil and was rated low for both surface and sub-surface soil. The result indicated that there was no significant difference in soil exchangeable acidity $\left(\mathrm{H}^{+}\right)$between coastal plain sand and basement complex rock $(t=1.28$, $d f=9, p>0.05)$ (Table 3). In this study, hydrogen ions rather than aluminum ions dominated the exchange acidity largely in agreement with reports of Amalu (1998) that $\mathrm{H}^{+}$rather than $\mathrm{Al}^{3+}$ dominates in majority of soils with $\mathrm{pH}$ less than 5 units. Exchangeable acidity $\left(\mathrm{Al}^{+++}\right)$in floodplain soil developed on coastal plain sand was not detected in surface soil, but ranged from $0.16-1.64 \mathrm{cmol} / \mathrm{kg}$ for subsurface soil with a mean value of 0.54 and was rated low. Similarly, exchangeable acidity $\left(\mathrm{Al}^{+++}\right)$in floodplain soil developed on coastal plain sand ranged from $0.18-$ 0.48 and $0.12-0.40$ for surface and sub-surface soil with a mean value of 0.28 and 0.26 for surface and subsurface soil respectively and was rated low for surface and sub-surface soil. Ambergor (2006) indicated that a concentration of aluminum ion greater than one $(>1$ $\mathrm{cmol} / \mathrm{kg}$ ) in the soil solution could lead to aluminium toxicity. The value of exchangeable Al obtained for this study may not result to Al toxicity to crop. Similarly, the 
value of exchangeable $\mathrm{H}^{+}$obtained for this study in the both soils will not be detrimental to crop growth.

\section{Base Saturation}

Base saturation (BS) in floodplain soil developed on coastal plain sand ranged from 93.11-95.50 and 54.30$89.00 \%$ for surface and sub-surface soil with a mean value of 94.6 and $80.66 \%$ for surface and sub-surface soil respectively and was rated high for both surface and sub-surface soil. Similarly, BS in floodplain soil developed on basement complex ranged from 31.0947.16 \% and 33.65-45.36 for surface and sub-surface soil with a mean value of 35.62 and 39.68 for surface and sub-surface soil respectively and was rated moderate for surface and sub-surface soil. The result also showed that there was a significant difference in soil BS between coastal plain sand and basement complex rock $(t=12.22$, df $=9, p<0.001$ ) (Table 3 ). Soil developed on coastal plain sand parent material had the highest BS than soil developed on basement complex rock. Akpan et al. (2017) also obtained high base saturation for wetland soil overlying coastal plain soil.

\section{CONCLUSION}

The result of this study has indicated that floodplain soils overlying coastal plain sand and basement complex parent materials showed no significant difference in physical properties studied but however, there were significant difference in key fertility indices (i.e. OC, N, P, Ca, ECEC, BS), thus both soils cannot be exploited for crop cultivation with similar management practices. Floodplain soil overlying coastal plain sand had high potential for crop production as it contains moderate amount of exchangeable $\mathrm{Mg}$, available $\mathrm{P}$, total $\mathrm{N}$ and organic carbon and is high in base saturation and low in exchangeable acidity. The soil is thus rated moderate in some key fertility indicators. This soil can be exploited for the cultivation of rice, oil palm, coconut, plantain, pineapple, pepper, fluted pumpkin and sugar cane with judicious application of lime, and $\mathrm{N}$ and $\mathrm{K}$ fertilizers. Conversely, the floodplain soil developed on basement complex in Awi was rated low in fertility. However, soil fertility management option in both areas should focus on liming and practices that will improve the soil organic matter, nitrogen and exchangeable cations ( $\mathrm{Ca}$ and $\mathrm{K}$ ) based on the soil test result.

\section{REFERENCES}

Abam, P. O and Orji, O. A., 2019. Morphological and Physico-Chemical Properties of Soils Formed from Diverse Parent Materials in Cross River State, Nigeria. Journal of Applied Geology and Geophysics, 7(1):1-7.

Afu, S. M., Isong, I. A. and Aki, E. E., 2017. Variability of selected physico-chemical properties of soil overlying different parent materials in Odukpani, Cross River State. International Journal of Plant and Soil Science, 20(6), 1-14.

Aki, E. E and Isong, I. A., 2018. Characterization of physico-chemical properties and micronutrients status of soil developed on Anantigha coastal marine sediment in Calabar. Global Journal of Agricultural Sciences, 17, 1-13.

Aki, E. E., 2012. Characterization of wetland soils developed on limestone parent material in Cross River State, South Eastern Nigeria. Global Journal of Agricultural Sciences, 11(1), 37-44.

Akpan, J. F., Aki, E. E. and I.A. Isong, I. A. 2017. Comparative assessment of wetland and coastal plain soils in Calabar, Cross River State. Global Journal of Agricultural Sciences, 16(1), 17-30.

Akpan-Idiok, P., Ogbaji, O. and Antigha, N.R.B., 2012. Infiltration, Degradation rate and vulnerability potential of Onwu river floodplain soils in Cross River State, Nigeria. J. Agric. Biotechnol. Ecol., 5,62-74.

Akpan-Idiok, A. U. and Ogbaji, P. O., 2013. Characterization and Classification of Onwu River Floodplain Soils in Cross River State, Nigeria. International Journal of Agricultural Research, 8, 107-122.

Amalu U. C., 1998 Evaluation of properties of selected soils of Cross River area and their management for increased cassava yields. Global Journal of Pure and Applied Sciences, 4(3): 243-249.

Amalu, U. C and Isong, I. A., 2018. Status and spatial variability of soil properties in relation to fertilizer placement for intercrops in an oil palm plantation in Calabar, Nigeria. Nigerian Journal of Crop Science, 5(2), 58-72.

Amalu, U. C. and Isong, I. A., 2017. Long-term impact of climate variables on agricultural lands in Calabar, Nigeria I. Trend analysis of rainfall, temperature and relative humidity. Nigerian Journal of Crop Science, 4(2):79-94.

Amalu, U. C. and Isong, I. A., 2015. Land capability and soil suitability of some acid sand soil supporting oil palm Elaeis guinensis Jacq trees in Calabar, Nigeria Special issue. Nigerian Journal of soil science, 25, $92-109$.

Amberger, A., 2006 Soil fertility and plant nutrition in the tropics IFA/IPL. Pp 96.

Attoe, E. E., Ojikpong, T. O. and Kekong, M. A., 2016. Evaluation of growth and yield parameters of two ginger varieties in different soils of Cross River State, Nigeria. European Journal of Academic Essays, 3(3): 109-120.

Ayalew, A. and Beyene, S., 2012. Characterization of Soils at Angacha district in Southern Ethiopia. J. Biol. Agric. Healthcare, 2, 6-16.

Brady, N. C. and Weil, R., 2002. The Nature and Properties of Soils. 13th edition. Singapore, Pearson Education. 976pp. 
Bremner, J. M., 1996. Total nitrogen. In: Sparks, D. L. (Ed.), Methods of Soil Analysis. Part 2 Chemical

Methods pp. 1085-1086. Soil Science Society of America. Madisn, WI

Browaldh, M., 1995. The influence of trees on nitrogen dynamics in an agrisilvicultural system in Sweden. Agroforestry System, 30(3): 301-313.

Chukwu, G. O., Chude, L.A., and Ekpo, L. E., 2009. Wetlands of southeastern Nigeria: Extent and Characteristics. Nigerian Journal of Agriculture, Food and Environment, 5(2-4), 42-46.

Daniel, S., Gabiri, G., Kirimi,F., Glasner, B., Näschen, K., Leemhuis, C., Steinbach, S., and Mtei, K., 2017. Spatial Distribution of Soil Hydrological Properties in the Kilombero Floodplain, Tanzania. Hydrology , 4, 57, 1-13.

Egbuchua, C. N. and Ojobor, S., 2011. Characterization of some hydric soils in the Niger-Delta region of Nigeria for land evaluation purposes. Int. J. Adv. Biol. Res., 1, 77-82.

Esu, I.E., Uko, U. and Aki, E. E., 2014. Morphological, physiochemical and mineralogical properties of soils developed from basalt at Ikom, cross river state, Nigeria. Proceeding of the 38th Annual Conference of Soil Science Society of Nigeria, March 10-14, 2014, Uyo, Nigeria, pp: 89-100.

Fertilizer Production, Distribution and Division FPDD 1990. Literature Review on soil fertility Investment in Nigeria published by Federal Ministry of Agriculture and Natural Resources, Lagos. pp. 281.

Gbadegesin, A. S., Abua, M. A. and Atu, J. E., 2011. Variation in soil properties on cassava production in the coastal area of Southern Cross River State, Nigeria. Journal of Geography and Geology, 3(1), 94-103.

Gee, G.W. and Or, D., 2002. Particle Size Analysis. In: Methods of Soil Analysis, Part 4, Physical Methods, Dane, J.H. and G.C. Topp (Eds.). ASA and SSSA, Madison, WI., pp: 255-293.

Global positioning system GPS. 2017. Data taken by the researcher using Magellan $®$ Global Positioning System.

Goudie, A. S., 2004. Encyclopaedia of Geomorphology. Vol. 1. Routledge, New York.

Hossain,M. M., Khan, Z. H. Hussain, M. S. and Mazumder, A. R., 2011. Characterization and classification of some intensively cultivated soils from the Ganges river floodplain of Bangladesh. Dhaka Univ. J. Biol. Sci., 20, 71-80.
Ibanga, I. J., Udoma, G. H., Edet, A. B. and Akpan F. S., 2005. Physico- chemical properties of some limestone soils in southeastern Nigeria. Nigerian Journal of soil science, 15:81-85.

Juo, A. S. R and Hosner, L. R., 1992. Resource conservation and sustainable agriculture on wet soils. Pp. 161-167.

In J. M. Kimble (ed) Characterization, Classification and Utilization of Wet Soils. Proc. VIII ISCOM, USDA Soil Conservation Service, National Soil Survey Centre, Lincoln, N.E.

Kuo, S., 1996. Phosphorus. In Methods of soil analysis, part 3: Chemical methods, ed. D. L. Sparks, 869-919. Madison, Wisc., SSSA.

Landon, J., 1991. Booker tropical soil manual: A handbook for soil survey and agricultural land evaluation in the tropics and subtropics. Longman, NY.

Lawal, B.A., Tsado, P.A., Eze, P.C., Idefoh, K.K., Zaki, A.A., Kolawole, S., 2014. Effect of Slope Positions on some Properties of Soils under a Tectona grandis Plantation in Minna, Southern Guinea Savanna of Nigeria. International Journal of Research in Agriculture and Forestry, 1(2), 3743.

McCartney, M., Rebelo, L. M, Senaratna, S. S. and de Silva, S., 2010. Wetlands, Agriculture and poverty Reduction. Colombo, SriLanka: International Water Management Institute. IW MI Research Report. Pp. 39.

Nelson, O. W. and Sommers L. E., 1996. Total Carbon, Organic Carbon and Organic Matter. In O. L. Sparks (ed).

Methods of Soil Analysis Part 3, Chemical Methods. Soil Science Society of America Book Series Number 5. American Society of Agronomy, Madison WIE, pp 961 - 1010.

Nigerian Meteorological Agency NIMET, 2015. Three years monthly weather data sheets 2012-2014. Margaret Ekpo International Airport, Calabar, Cross River State, Nigeria.

Nsor, M. E., 2017. Soil characteristics and fertility capability classification of soils of limestone lithology along a toposequence in Cross River State, Nigeria. Nigerian Journal of Agriculture, Food and Environment, 13(3), 96-101.

Ogban P. I. and Ibia T. O., 1998 Characteristics and crop production Potentials of wetland Soils from South Eastern Nigeria. Nig. J. Agric. Tech., 7, $78-84$. 
AFU, S. M., ISONG, I. A. AND AWAOGU, C. E.

Ogban, P. I. and Babalola, O., 2009. Characteristics, classification, and management of inland valley bottom soils for crop production in sub-humid southwestern Nigeria. Agro-Sci. J. Trop. Agric., Food, Environment and Extension, 8(1), 1-13.

Ogban, P.I., Effiong, G.S., Obi, J.C. and Ibia T.O., 2011. Characteristics, potentials and constraints of wetland soils for agricultural development in Akwa Ibom State, southeastern Nigeria, Nigerian Journal of Agriculture, Food and Environment, 7(2):80- 87

Oguike, P. C. and Mbagwu, J. S. C., 2009. Variations in some physical properties and organic matter content of soils of coastal plain sand under different land use types. World J. Agric. Sci., 5, 63-69.

Oku, E., Essoka, A. and Thomas, E., 2010. Variability in soil properties along an udalf toposequence in the humid forest zone of Nigeria. Nat. Sci., 44 : $564-573$.

Onyekwere, I. N. Akpanidiok, A. U, Amalu, U. C., Asawalam, D. O and Eze, P. C., 2001 Constraints and opportunities in agricultural utilization of some wetland soils in Akwa Ibom State. Proc. of 27th Annual Conf. of Soil Science Society of Nigeria, pp $139-146$.

Oparaeke, A.M. and Ofor, M. O., Ibeawuchi I. I., 2010. Global Food Crisis and its Implications in Nigeria. Journal of American Science, 6(5), 7779.

Reddy, K. R., and Delaune, R., 2008. Biogeochemistry of wetlands: Science and Applications. CRC Lewis Publishers; Boca Raton, Florida. 678pp.

Thomas, G. W., 1982. Exchangeable cation, In Page A.L. et al (eds) Method of Soil Analysis. Part 2, Agron Monograph, a second edition, ASA and SSA, Madison, Wisconsin. PP 159-165.

Udo, E.J., Ibia, T. O., Ogunwale, J. A., Ano, A. O., and Esu, I. E., 2009. Manual of Soil, Plan and Water Analyses. Sibon Books Limited, Lagos, Nigeria, pp. 183.

Ukabiala, M. E., Kefas, P. K., Akpan-Idiok, A. U., Philip, H. J., Ngasoh, F. G. and Kefas, A. P., 2016. Assessment of the physicochemical characteristics, degradation rate and vulnerability potential of Ihitte/Uboma Soils, Imo State, Nigeria. International Journal of Agriculture and Environmental Research, 2(5), 1467-1479.

Ukpong, I. E., 2000. Ecological classification of Nigeruian mangrove using soil nutrient gradient analysis. Wetlands Ecol. Manag., 8, 263-272.

United Nations, Department of Economic and Social Affairs, Population Division 2015. World Population Prospects: The 2015 Revision, Volume I: Comprehensive Tables (ST/ESA/SER.A/379).

Uzoho, B. U., Ekpe, I. I., Ahukaemere, C. M., Ndukwu, B. N., Okoli, N. H., Osisi, F. A. and ChrisEmenyonu, C. M., 2014. Nitrogen Status of Soils of Selected Land-uses of Two Cropping Systems in the Humid Tropical Rainforest, Southeastern Nigeria. Advances in Life Science and Technology, 25, 24-33.

Valiela, I. and Teal, J. M., 1974. Nutrient limitation in salt marsh vegetation. In Reimold, R. J. and Queen W. H. (eds). Ecology of Halophytes. Acedemic press, New york, pp. 547-563.

Yakubu, M. and Ojanuga, A. G., 2009. Pedogenesis, weathering status and mineralogy of the soils on ironstone Plateau (Laterites). Sokoto, Nigeria.

Yebo, B., 2015. Integrated soil fertility management for better crop production in Ethiopia. International Journal of Soil Science, 10, 1-16.

Yusuf, A. A. and Yusuf, H. A., 2008. Evaluation of strategies for soil fertility improvement in Northern Nigeria and the way forward. Journal of Agronomy, 7, 15-24. 